\title{
Penis Kanserlerine Genel Bakış
}

\section{An Update on Cancers of Penis}

\author{
Dr. Ali Furkan Batur \\ Sincan Devlet Hastanesi, Üroloji Kliniği, Ankara, Türkiye
}

\section{Özet}

Penis kanserleri nadir görüldükleri için sıklıkla tanısı atlanabilen malignitelerdir. Penis kanserlerinin çok büyük bir kısmını karsinoma in situ veya invazif skuamöz hücreli karsinoma oluşturmaktadır. Penis kanserleri ile ilişkili risk faktörleri arasında; fimozis, kronik penis inflamasyonu (fimozis ilişkili balanopostit), human papilloma virus enfeksiyonu hikayesi ve yoğun cinsel yaşam hikayesi bulunmaktadır. Primer lezyonun ilk prezentasyonu göreli olarak göze çarpmayan bir şişlik, küçük bir papül, siğilimsi büyüme veya papiller ekzofitik lezyona kadar değişebilen bir aralıkta olabilir. Tanı lezyondan şüphelenilmesiyle başlar ve biopsi ile neticelenir. Primer lezyonun değerlendirilmesinde fizik muayene çoğunlukla yeterliyken, inguinal lenfadenopati olduğundan şüphelenilen hastalarda tanı için modifiye inguinal lenfadenektomi veya dinamik sentinel nod biopsisi yapılabilir. Primer lezyonun tedavisinde topikal kemoterapi, lazer, radyoterapi ve cerrahi eksizyon seçenekleri bulunmaktadır. Inguinal lenfadenopati saptandığında tedavi cerrahidir. Bu derlemede özellikle sünnet olma alışkanlığından dolayı ülkemizde nadir görülen penis kanserlerinin tanısı ve tedavisindeki güncel bilgilerin hatırlatılması amaçlanmıştır. (Üroonkoloji Bülteni 2014;13:146-152)

Anahtar Kelimeler: Penis kanseri, fimozis, sünnet, skuamöz hücreli karsinom

\section{Summary}

Cancers of penis are uncommon malignancies that are often misdiagnosed. Carcinoma in situ or invasive squamous cell carcinoma constitutes most of the malign penile carcinomas. Risk factors related to penile cancer are listed as phimosis, chronic penile inflammation (balanoposthitis related to phimosis), human papilloma virus infections, and intensive sexual life. The presentation of primary lesion ranges from a relatively subtle induration to a small papule, pustule, warty growth, or papillary exophytic lesion. Diagnosis starts with the suspicion of this primary lesion, and ends up with the biopsy. The diagnosis of the primary lesion can be made by physical examination, but modified inguinal lymphadenectomy or dynamic sentinel-node biopsy is needed to diagnose in case of the doubt of inguinal lymphadenopathy. Treatment approaches to the primary lesion are topical chemotherapy, laser therapy, radiotherapy, and surgical excision. Treatment of the inguinal lymphadenopathy is mostly includes surgery. We aimed to remind the updates on the diagnosis and treatment of penile cancer which is seen rarely related to the circumcision tradition in our country in this review. (Bulletin of Urooncology 2014;13:146-152)

Key Words: Cancer of penis, phimosis, circumcision, squamous cell carcinoma

\section{Giriş}

Penis kanserleri, nadir görüldüğü için tanısı ve özellikle tedavisi konusunda ürologları zorlayan bir hastalık grubudur. Penis kanserlerinin çok büyük bir kısmını karsinoma in situ (CIS) veya invazif skuamöz hücreli karsinoma (SHK) oluşturmaktadır. Erken tanı konulduğunda \%80 oranında kür sağlanabilen bu malignitelerin sıklığı, risk faktörlerinin de günümüz dünyasında daha da etkin hale gelmesiyle gittikçe artmaktadır. Bu derleme yazısında amaç penis kanserlerine genel bir bakış yapmak ve tanısı ile tedavisindeki yeni gelişmeleri hatırlatmaktır.

\section{Skuamöz Hücreli Karsinoma}

\section{Karsinoma İn Situ (CIS)}

CIS, SHK'nın intraepitelyal malign gelişimi olarak tanımlanmaktadır. Glans penis veya prepisyumdaysa 'Queyrat eritroplazisi', penis şaft ve/veya genital bölgenin geri kalanında bulunursa 'Bowen hastalığı' ismini almaktadır. Ancak isimleri ne olursa olsun histopatolojik özellikleri birbirine çok benzer bu iki antite kısaca CIS olarak tanımlanır ve bulunduğu yere göre tedavi edilir (1). Bu lezyonlar ilk olarak makroskopik olarak kırmızı, kadife görünümlü, genel olarak sınırları belirgin olarak görüntü verirler (Şekil 1). İlerleyen dönemde eğer tanı 
konulmamış ve tedavi edilmemiş ise ağrılı ve akıntılı olabilen ülsere bir hal alabilirler. Histopatolojilerinde normal mukozanın yerini vakuolize olmuş, düzensiz, displastik ve nükleer atipi gösterebilen diskeratik hücrelerin almış olduğu gözlenir. Yatkınlık oluşturan faktörler olarak sünnetsiz olmak ve human papilloma virüsü (HPV) lezyonları suçlanmaktadır (2). İnvazif karsinomaya ilerleme için \%10 ile \%33 arasında değişen oranlar verilmektedir ancak çok geniş olgu serileri bulunmadığı için tam bir oran vermek mümkün değildir $(3,4)$. Visseral malignitelerle bağlantılarının olmadığı bildirilmektedir. Ayırıcı tanılarında invazif SHK, bowenoid papüllozis, egzema, psöriazis ve yüzeyel bazal hücreli karsinoma yer almaktadır (1). Tedavi seçenekleri olarak cerrahi, topikal kremler, topikal lazer ablasyon ve radyoterapi (RT) bulunmaktadır. Cerrahi olarak $5 \mathrm{~mm}$ güvenlik sınırlı cerrahi eksizyon veya bulunduğu yere göre parsiyel sirkümsizyon yapılmaktadır (1). Topikal olarak da 5-fluorourasil (5-FU) veya $\% 5$ imiquimod krem kullanılabilmektedir (5). Lazer ablasyon

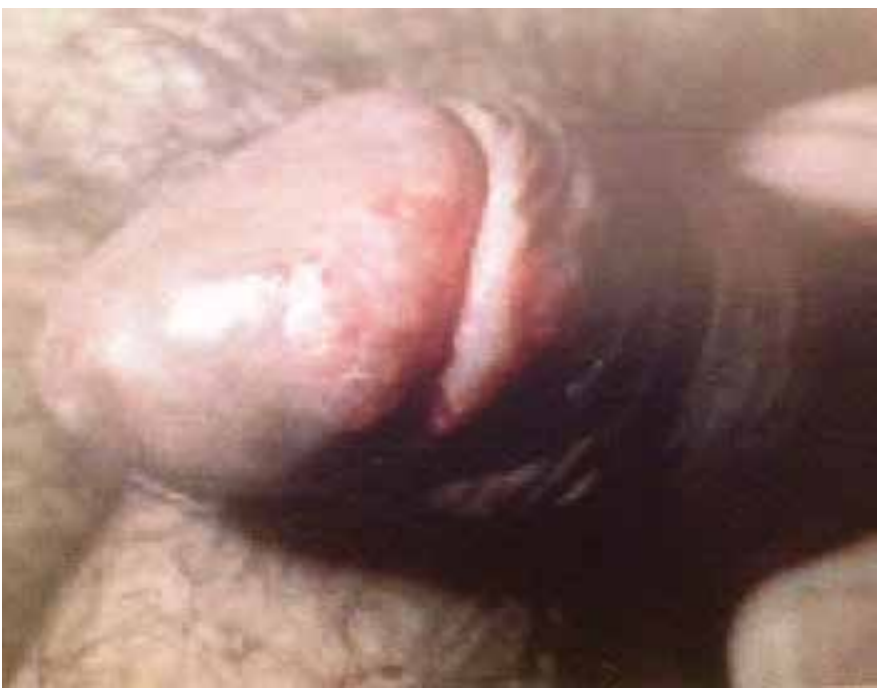

Şekil 1. Karsinoma in situ (Dr. Levent Türkeri'nin izniyle) (2)

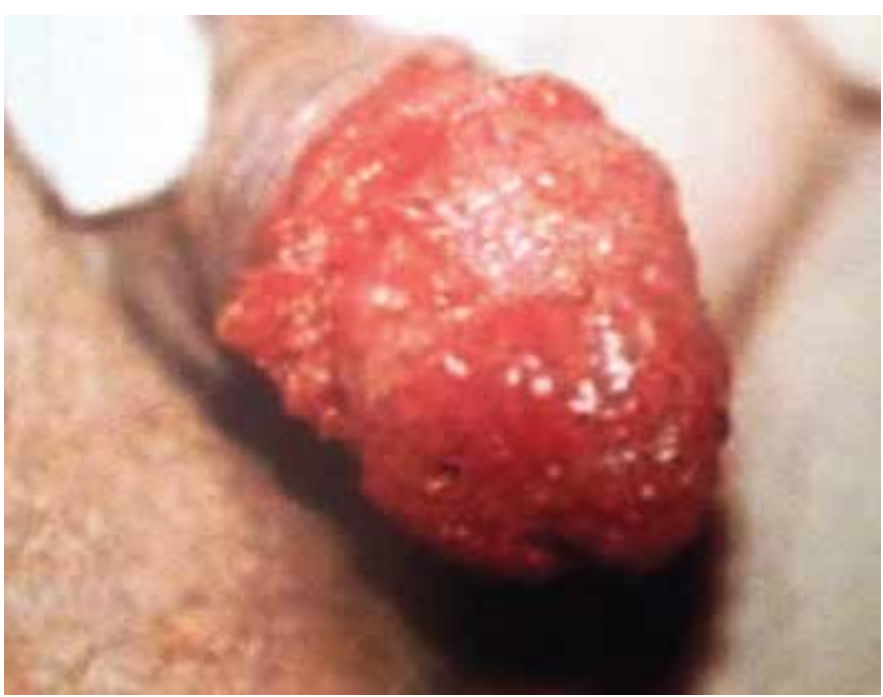

Şekil 2. İnvazif skuamöz hücreli penis karsinomu (ülsere) (Dr. Levent Türkeri'nin izniyle) (2) seçenekleri olarak Neodimium:Ytrium-aluminyum-garnet (Nd:YAG), Potasyum titanil fosfat 532-nm veya karbondioksit $\left(\mathrm{CO}_{2}\right)$ kullanılabilmektedir. RT seçeneği tedavide daha alt sıralarda tercih edilir ve çoğunlukla topikal tedavilere dirençli tedaviler için düşünülmektedir (1).

\section{İnvazif Karsinoma}

Penis kanserleri içinde en sık olarak SHK görülmekle beraber bazı diğer karsinoma tipleri de çok nadir olarak görülebilmektedir. Çoğunlukla prepisyum veya glansın epitelinden kaynaklanmaktadırlar. Orofarinks, kadın genital sistemi (serviks, vajina ve vulva) ile anüsün SHK ile benzer patolojik özellikler taşımaktadırlar ve bu özellik bize bu nadir görülen kanserler için uygun kemoterapi yönetimine yardımcı olmaktadır. Penis kanserleri için çeşitli epidemiyolojik rakamlar verilmesine karşın Güney Amerika, Güneydoğu Asya ve Afrika kıtasının bazı kısımlarında erkek malignitelerinin arasında \%1-\%2 gibi yüksek oranlarda bulunduğu belirtilmektedir. Bu ülkelerin toplumlarının genel özelliklerine bakıldığında sünnet olma alışkanlığının olmaması ve HPV'nin yaygın olduğu göze çarpmaktadır. Kuzey Amerika'da penis kanseri görülme sıklığı beyaz hispaniklerde belirgin olarak fazladır (6). Cinsel partner sayısının gittikçe arttığı günümüzde HPV enfeksiyonlarının da yaygınlaşmasıyla penis kanserinin sıklığının artacağı öngörülmektedir (1).

\section{Etiyoloji}

Penis kanserlerinin etiyolojisinde yer alan risk faktörlerinden en belirgin olanları şunlardır: Fimozis, kronik penis inflamasyonu (fimozis ilişkili balanopostit), balanitis kserotica obliterans (liken sklerozis), sporalen ve UV-a fototerapisi hikayesi, HPV enfeksiyonu hikayesi, condyloma aküminata hikayesi, erken yaşta başlayan ve bir çok cinsel partnerle devam eden yoğun cinsel yaşam hikayesi, sigara içiciliği (7).

Fimozisin risk faktörü olmasına sebep olarak smegmanın yarattığı kronik inflamasyon gösterilmektedir ve bu açıdan neonatal sirkümsizyonun dinsel ve geleneksel amaçla uygulandığı ülkelerde SHK görülme sıklığının çok aza indiği belirtilmektedir (6).

HPV tiplerinden 6 ve $11^{\prime}$ in benign genital siğillerle ilişkili olduğu ve 16, 18, 31 ve 33'ün SHK ile ilişkili olduğu tespit edilmiştir. Bunlar arasından da özellikle HPV tip 16'nın ciddi risk yarattığı, hatta metastatik olgularda en çok rastlanılan tipin bu olduğu tespit edilmiştir (8). Penis kanserini önleme çalışmaları arasında iyi belirlenmiş ve sık görülen HPV tiplerine karşı aşı da geliştirilmiştir, ancak bu aşılar kişi cinsel yaşama başlamamışsa etkili olabilmektedir. Bu aşılar HPV 16 ve 18 Cervarix (GlaxoSmithKline) ve HPV 16/18/6/11 quadrivalent Gardais'dur (Sanofi Pasteur, Merck Shape \& Dome) (1).

\section{Hastalığın Doğal Seyri ve Tanı}

Penis kanserlerinin \%80'lik bir kısmı tam olarak iyileştirilebilir ancak bir defa metastatik yayılım olduğunda kötü bir prognoz göstermektedir. Bunun yanında psikososyal iyi olma hali için tedavi sonucunda fonksiyonel ve güzel kozmetik sonuçlara sahip bir penisin olması da önemlidir (6). Bu anlamda da erken tanı çok önemlidir. Başlarken tipine bağlı olmak üzere papiler ve ekzofitik veya düz ve ülseratif bir lezyon şeklinde olabilir. Başlangıçta bu lezyon ağrılı değilken sonradan ağrıı, akıntılı ve yaygın ülsere hale gelebilir (Şekil 2). Burada dikkat edilmesi gereken diğer bir nokta prepisyumdan köken alma sıklığını düşünüldüğünde muayenede sünnetsiz hastalarda prepisyumun dikkatlice muayene edilmesi gerekliliğidir. Eğer primer lezyona 
tanı konulamazsa hastalık penil otoamputasyona kadar ilerleyebilmektedir (1). Hastalığın doğal seyri üzerine yapılan çalışmalarda düz ve ülsere lezyonların prognozunun papiller olanlara göre belirgin olarak daha kötü olduğu bulunmuştur. Ayrıca 5 cm'den büyük lezyonlar ve penis şaftının \%75'inden fazlasını tutan lezyonların artmış metastaz riski ve azalmış yaşam süresi ile ilintili olduğu da tespit edilmiştir (9).

Tanı kısaca peniste görülen hiperemik, düzgün sınırlı, papül, püstül, siğilimsi büyüme, papiller veya düz lezyondan şüphelenilmesi ve buradan biopsi yapılması ile konulmaktadır. Penis kanserlerinin peniste bulunduğu yere göre görülme sıklığı oranları şu şekildedir: glans \%48, prepisyum \%21, koronal sulkus \%6, penis şaftı \%2. Çok nadiren hasta prepisyumun altına gizlenmiş lezyonu fark etmediğinde inguinal bölgede nodal metastazlara işaret eden kitle, ülserasyon, süpürasyon, hemoraji şikayeti veya üretral tutuluma bağlı üriner retansiyon veya üretral fistül ile başvurabilen hastalar olabilmektedir. Lezyon genellikle ağrısız olmaktadır ancak kronik süpürasyona bağlı güçsüzlük, kilo kaybı, iştahsızlık gibi sistemik şikayetler de olabilmektedir. Tanıda gecikme; hastanın lezyonu önemsememesi veya doktora başvurmaya utanması ile doktorun doğru tanıyı koyamamasından dolayı olabilmektedir.

Fizik muayenede lezyon tanımlandıktan sonra korporeal yapıların tutulup tutulmadığı dikkatlice değerlendirilmelidir. Rektal ve bimanuel muayenede perineal yapıda tutulum olup olmadığı ve pelvik kitle olup olmadığı değerlendirilmelidir. Ayrıca inguinal lenfadenopati (LAP) muayenesi dikkatli bir şekilde yapılmalıdır.

\section{Biopsi ve Patoloji}

Tanıdan şüphelenildiğinde biopsi cerrahiden ayrı bir işlem olarak veya planlı cerrahi öncesi frozen inceleme yöntemi olarak yapılabilir. Biopsi sonucu SHK'ları destekleyen bulgular epitelyum hücrelerinde keratinizasyon, inci oluşumu ve çeşitli derecelerde mitotik aktivite artmasıdır (1). SHK malign penis lezyonlarının \%95'lik kısmını oluşturmaktadır. Penis kanserlerinin kalan kısmını oluşturan maligniteler arasında melanositik lezyonlar, mezenşimal tümörler, lenfomalar ve metastazlara bağlı sekonder tümörler (prostat veya kolorektal kökenli) yer almaktadır.

SHK'lerin alt tipleri hastalığın gidişatı açısından önemlidir. Bu yüzden patolojik olarak alt tip ve HPV ilişkisinin belirtilmesi prognozun öngörülebilmesi açısından önemlidir (Tablo 1). Penis kanseri biopsi veya rezeksiyon spesimeninde belirtilmesi gereken patolojik özellikler şunlardır: primer tümörün anatomik lokalizasyonu, histolojik tip ve alt tip, derece, perinöral invazyon, invazyonun derinliği, lenfatik ve venöz vasküler invazyon, irregüler büyüme paterni, üretral invazyon, korpus spongiozum ve kavernozum invazyonu ve cerrahi sınırlar.

Patolojik prognostik faktörler değerlendirildiğinde karşımıza birkaç tane gösterge çıkmaktadır:

1. Prepisyuma sınırlı karsinomalar daha iyi prognoza ve düşük rejyonel metastaz potansiyeline sahiptirler.

2. Perinöral invazyon varlığı ve histolojik derece kansere bağlı ölüm oranları artışı ve kötü prognoz açısından çok kuvvetli göstergelerdir.

3. Lenfatik invazyon varlığı bağımsız bir faktör olarak metastaz için önemli bir göstergedir.

4. SHK alt tiplerinden verrükoz, papiller, siğilimsi, psödohiperplastik ve karsinoma kunnikulatum çok iyi prognoza sahiptirler; bazaloid, sarkomatoid, adenoskuamöz ve undifferensiye alttipler kötü prognoza sahiptirler (6).

\section{Laboratuvar}

Penis kanserlerinde laboratuvar değerlendirmelerinde çoğunlukla hastalığa özgün bir bulgu bulunmamaktadır. Kronik hastalık anemisi, lökositoz ve hipoalbuminemi olabilmektedir. Eğer hastalık üretrayı tutarak işeme disfonksiyonuna yol açtıysa azotemi de görülebilmektedir. Kemik metastazı olmadan

\begin{tabular}{|c|c|c|c|}
\hline Histolojik Alt Tip & Hpv ilişkisi (varsa yüzdesi) & $\begin{array}{l}\text { Penis Kanserleri İçinde } \\
\text { Görülme Sıklığı }\end{array}$ & Prognoz \\
\hline Genel SHK & $\begin{array}{l}\text { HPV + (Değişen oranlar } \\
\text { verilmekte) }\end{array}$ & $\% 48-\% 65$ & Evre, derece ve yerleşime bağlı değişiyor \\
\hline Bazaloid karsinoma & HPV + \%76 & $\% 4-\% 10$ & Kötü prognoz, Erken lenf nodu metastazı \\
\hline Siğilimsi karsinoma & $\mathrm{HPV}+\% 36$ & $\% 7-\% 10$ & lyi prognoz \\
\hline Verrüköz karsinoma & HPV - & $\% 3-\% 8$ & lyi prognoz \\
\hline Papiller karsinoma & HPV - & $\% 5-\% 15$ & Iyi prognoz \\
\hline Sarkomatoid karsinoma & $?$ & $\% 1-\% 3$ & Çok kötü prognoz, Erken vasküler yayılım \\
\hline Psödohiperplastik karsinoma & $?$ & $<1$ & lyi prognoz \\
\hline Karsinoma kunnikulatum & $?$ & $<1$ & lyi prognoz \\
\hline Psödoglandüler karsinoma & $?$ & $<1$ & Kötü prognoz, erken metastaz \\
\hline Siğilimsi-bazaloid karsinoma & HPV + \%82 & $\% 9-\% 14$ & Kötü prognoz, yüksek metastaz riski mevcut \\
\hline Mukoepidermoid karsinoma & $?$ & $<1$ & Çok agresif davranışlı, ktü prognoz \\
\hline Berrak hücreli penis karsinoma & $?$ & $\% 1-\% 2$ & Çok nadir, kötü prognoz, sık lenfatik metastaz \\
\hline
\end{tabular}


hiperkalsemi olabildiği bildirilmiştir. Buna neden olarak da salınan paratiroid hormon benzeri maddelerin osteoklastik kemik rezorpsiyonuna yola açabildiği iddiasında bulunulmuştur (10).

\section{Radyolojik Değerlendirme}

Primer penis tümörünün değerlendirilmesinde fizik muayene tek başına yeterlidir. Ultrasonografi (USG) veya manyetik rezonans görüntüleme (MRG) belli noktalarda tıkanmaktadır. Ancak USG kopus kavernozum invazyonunun gösterilmesinde yüksek sensitiviteye sahiptir. Ayrıca korpus kavernozumun tutulduğu fizik muayene ile şüphelenilen olgularda evreleme yapmak amacıyla prostoglandin E1 ile oluşturulan yapay ereksiyon halinde yapılacak kontrastlı MRG faydalı bilgiler vermektedir (11). Bilgisayarlı tomografinin (BT) yumuşak doku rezolüsyonu düşük olduğu için primer lezyon derinliğinin değerlendirilmesinde yeri bulunmamaktadır (12). Lont ve ark. primer penil lezyonunun derinliğinin değerlendirildiği ve fizik muayene, USG ve MRG'nin karşılaştırıldığı çalışmalarında 33 hastanın verilerine bakarak fizik muayenenin yeterli olduğu sonucuna ulaşmışlardır (13).

Penis kanserlerinde inguinal lenf nodu değerlendirmesi hastalığın gidişatını ve uygun tedavi stratejisini belirlemekte çok önemlidir. $\mathrm{Bu}$ anlamda inguinal ve pelvik bölgede LAP değerlendirilmesi amacıyla bazı radyolojik yöntemlere başvurulabilmektedir. Her iki taraf inguinal bölgenin LAP açısından ayrıntılı fizik muayenesi penis kanserlerinde altın kurallardan bir tanesidir. Değerlendirme yapılırken palpe edilen lenf nodlarının lateralitesinin, fikse olup olmadığının ve sayılarının yaklaşık olarak kaç olduğunun belirtilmesi gerekmektedir. Ancak kilolu ve obez hastalarda fizik muayene her zaman doğru sonuç verememektedir. Bu nedenle penis kanserlerinde inguinal ve pelvik alanların LAP açısından radyolojik olarak incelenmesi her zaman araştırılan bir konu olmuştur. Tarihsel olarak değerlendirildiğinde uzun bir zaman BT eşliğinde lenfanjiografinin etkinliği tartışılmıştır. Ancak hem işlemin uygulama güçlüğü hem de yeterli güvenilirlikte sonuçlara ulaşılamaması bu metottan vazgeçilmesine neden olmuştur. Bununla ilgili yapılmış en geniş hasta serili çalışmalardan bir tanesi olan Horenblas ve ark'nın yaptığı 102 hastalık çalışmada, sensitivite sadece \%36 olarak çıkmıştır (14). İnguinal bölgedeki LAP'ların BT ile değerlendirilmesi, fizik muayene ile palpabl nodlardan yapılacak biopsinin BT eşliğinde olması ve sonucuna göre hastalara neoadjuvant kemoterapi (KT) planlanmasına yardımcı olabilmektedir. Yine Tabatabei ve ark.'nın penis kanserli hastalarda mikroskopik lenf nodu metastazını değerlendirmek için ferumokstran-10 parçacıkları $(35 \mathrm{~nm})$ verilmiş hastalarda MRG ile yaptıkları çalışmalar ümit vericidir. Yedi hasta hasta ile yapılan bu çalışmada lenfotropik nanopartikül ile güçlendirilmiş MRG'de (LNMRG) palpe edilmeyen ve 1 cm'den daha küçük olan inguinal LAP'ler \%100 oranda tespit edilebilmiştir (15). Son olarak da SHK'nın radiofarmositik fluorodeoksiglukozu (FDG) tuttuğu belirlendikten sonra FDG ile yapılan pozitron emisyon tomografisi (PET) ile yapılan çalışmada \%80 sensitivite saptanmış ve bu gelişme de umut verici olarak belirtilmiştir (16). Sık uzak metastaz alanları azalan sırayla akciğer, kemikler ve karaciğerdir. Bu metastaz alanlarının değerlendirilmesi abdominal ve pelvik BT, radyonüklid kemik taraması ve akciğer grafisi ile yapılmaktadır. Penis kanserlerinde henüz okkült mikrometastaz veya uzak metastazları gösteren herhangi bir tümör belirteci bulunmamaktadır (12).

\begin{tabular}{|c|c|}
\hline \multicolumn{2}{|l|}{ Klinik ve Patolojik Sınıflandırma } \\
\hline \multicolumn{2}{|l|}{ T - Primer Tümör (Klinik ve patolojik sınıflandırma aynıdır) } \\
\hline \multicolumn{2}{|l|}{$\begin{array}{l}\text { TX Primer tümör değerlendirilemiyor } \\
\text { T0 Primer tümöre dair kanıt yok } \\
\text { Tis Karsinoma in situ } \\
\text { T1 Primer tümör subepitelyal bağ dokuyu tutmuş } \\
\text { T1a Lenfovasküler invazyon yok ve iyi farklış̧mı̧ (T1G1) } \\
\text { T1b Lenfovasküler invazyon var ve/veya orta/az farklılaşmış (T1G2/G3) } \\
\text { T2 Korpus spongiozum ve/veya korpus kavernozum tutulumu var (?) } \\
\text { T3 Üretra tutulumu var (Proksimal-Distal ayrımı?) } \\
\text { T4 Tümör bitişik organları tutmuş (Mesane, prostat) }\end{array}$} \\
\hline N- Bölgesel lenf nodları (Klinik) & pN- Bölgesel lenf nodları (Patolojik) \\
\hline $\begin{array}{ll}\text { Nx } & \text { BLN değerlendirilemiyor } \\
\text { N0 } & \text { Görülebilen veya palpe edilebilen Ing. LN yok } \\
\text { N1 } & \text { Palpabl, hareketli ve unilateral İng. LN var } \\
\text { N2 } & \text { Palpabl, hareketli, multipl, unilateral veya bilateral ing. LN var } \\
\text { N3 } & \text { Fikse inguinal nodal kitle veya pelvik LAP (Unilateral veya bilateral) }\end{array}$ & $\begin{array}{ll}\text { Nx } & \text { BLN değerlendirilemiyor } \\
\text { N0 } & \text { BLN metastazı yok } \\
\text { N1 } & \text { Bir tane Ing. LN'de intranodal metastaz var } \\
\text { N2 } & \text { Multipl veya bilateral Ing. LN'de metastaz var } \\
\text { N3 } & \text { BLN'de ekstranodal tutulum var veya pelvik } L N^{\prime} \text { 'de tutulum var }\end{array}$ \\
\hline \multicolumn{2}{|l|}{ M-Uzak metastaz (Klinik ve patolojik sınıflandırma aynıdır) } \\
\hline \multicolumn{2}{|c|}{$\begin{array}{l}\text { M0 Uzak metastaz yok } \\
\text { M1 Uzak metastaz var (Retroperitoneal LN tutulumu Bölgesel LN alanı dışında kalır ve dolayısıyla bu gruba dahil olur) }\end{array}$} \\
\hline \multicolumn{2}{|l|}{ G- Histopatolojik sınıflandırma } \\
\hline \multicolumn{2}{|l|}{$\begin{array}{ll}\text { GX } & \text { Farklılaşma derecesi değerlendirilemiyor } \\
\text { G1 } & \text { lyi derecede farklılaşmış } \\
\text { G2 } & \text { Orta derecede farklılaşmış } \\
\text { G3 } & \text { Zayıf derecede farklılaşmış/farklılaşmamış }\end{array}$} \\
\hline
\end{tabular}




\section{Evreleme}

Penis kanserlerinin evrelemesinde 2009 TNM klinik ve patolojik sınıflandırma sistemi kullanılmaktadır (Tablo 2) (6). Ancak araştırmalar neticesinde bazı otörler bu son evreleme sisteminin de bazı kısıtlamaları olduğunu tespit etmişler ve revizyona ihtiyacı olduğunu belirtmişlerdir. Belirtilen kısıtlamalar ve çözüm önerileri şu şekilde özetlenebilir:

1. T2'ye dahil edilmiş olan korpus spongiozum ve korpus kavernozum tutulumlarından korpus kavernozum tutulumu belirgin olarak daha kötü prognoza işaret etmektedir. Çözüm önerisi T2a. Korpus spongiozum tutulumu, T2b. Korpus kavernozum tutulumu şeklindedir (1). Hatta Horenblas ve ark. bu ikisini ayrı T sınıfına (T2 ve T3 şeklinde) yerleştirmeyi önermektedirler (17).

2. T3'e dahil edilmiş olan üretral tutulumlar; proksimal ve distal üretra tutulumu şeklinde ayrım yapmamaktadır. Proksimal üretra tutulumu belirgin olarak daha kötü prognoza işaret etmektedir. Çözüm önerisi T3a. Distal üretra tutulumu, T3b. Proksimal üretra tutulumu şeklindedir.

\section{Tedavi}

Primer Tümörün Tedavi Yönetimi

Penis kanserlerinin tedavilerinde temel amaç onkolojik prensiplerden vazgeçmeden olabildiğince fazla organ koruyucu yaklaşım uygulayabilmektir. Lokalize penis kanserlerinde bir çok tedavi metodu uygulanmışsa da bunların etkinliğini karşılaştıran randomize kontrollü çalışma bulunmamaktadır. Bu da primer lezyonun tedavisinde seçimi zorlaştırmaktadır. Eğer cerrahi tedavi planlanmamışsa tedavi öncesi tanı mutlaka biopsi ile doğrulanmalıdır (6).

\section{Karsinoma İn Situ Tedavisi}

Penil CIS için ilk tedavi seçeneği imiquimod veya 5-FU ile uygulanılan topikal tedavidir. Toksisite ve yan etkiler az olmakla beraber tedavinin etkinliği de düşüktür. Eğer topikal tedavi sonrası rekürrens gelişirse tekrar bir topikal tedavi seçeneği uygulanmamalıdır. CIS için diğer bir tedavi seçeneği lazer tedavisidir (özellikle $\mathrm{CO}_{2}$ ). Diğer tedavi seçeneği olarak cerrahi kalır ki bu genellikle primer tedavi rekürrensinde uygulanılır. Burada lezyonun büyüklüğüne göre cerrahiye karar verilir (18).

\section{Ta/T1a Kategorisi Tedavisi}

Küçük ve lokalize invaze penil lezyonları (Ta/T1a) tedavisinde penis koruyucu tedavi yaklaşımları uygulanılır. Cerrahi olmayan bir tedavi seçeneği uygulanılacaksa öncelikle hastaya sirkümsizyon uygulanılır. Prepisyuma sınırı tümörlerde radikal sirkümsizyon yeterli olabilir. Onkolojik olarak $5 \mathrm{~mm}$ negatif cerrahi sınır güvenli olarak kabul edilmektedir (19). Cerrahi tedavi seçenekleri olarak Mohs mikrografik cerrahisi, glans resurfacing (sadece glans derisinin alınması), glansektomi ve parsiyal penektomi vardır. Bunlardan Mohs mikrografik cerrahisi çok sınırlı bir grup tarafından uygulanmış ve artık uygulanmamakta olan bir metoddur. Glans cerrahileri komplikasyon oranları az olan ve sonuçları uygun hasta seçimiyle olumlu olan tedavi seçenekleridir. Bu evrede hastalığın seyri de olumlu olduğu için bu cerrahiler sonrası rekürrens oranları oldukça düşüktür. Parsiyel penektomi seçeneği bu grup hasta için fazla bir tedavi olarak değerlendirilebilmektedir. Ancak çok seçilmiş ve diğer tedavilere yanıt vermeyen hasta grubunda endikedir (20). Cerrahi olmayan tedavi seçenekleri olarak bu hasta grubunda lazer tedavisi öne çıkmaktadır. Lazer tedavi seçeneklerinden $\mathrm{Nd}$ :YAG veya $\mathrm{CO}_{2}$ lazer kullanılabilir. Ta/T1a hasta grubunda primer tümörün tedavisi için $\mathrm{CO}_{2}$ lazer tedavisinin kullanıldığı 3 çalışma bulunmaktadır. Bu çalışmalara göre sonuçta lokal rekürrens oranları \%11-\%26 arasında verilmektedir. Kanama ve enfeksiyon gibi hafif komplikasyonlar bildirilmektedir. On yıl sonunda sekonder parsiyel penektomi uygulama oranları \%3 ile \%10 arasında verilmiştir (21). Nd:YAG lazerin değerlendirildiği 4 çalışmada toplam 150 hasta tedavi ve takip edilmiştir. Bunların ortak sonuçlarına göre ciddi komplikasyon bildirilmemiştir. Sekonder parsiyel penektomi uygulama oranları \%4 ile \%45 arasında değişmektedir. Beş yıllık kansersiz sağ kalım oranları yaklaşık olarak \%95 olarak bildirilmiştir $(22,23)$.

RT 4 cm'den daha küçük lezyonlar için uygulanabilecek bir tedavi seçeneğidir. Brakiterapi ile kombine bir şekilde 60 gy eksternal RT veya sadece brakiterapi olarak verilebilir. Brakiterapi ile ilgili yapılan çalışmalarda lokal rekürrens oranları \%10-\%30 arasında verilmektedir. Bu tedavi seçeneği ile ilgili en büyük sorun \%40 gibi çok yüksek oranda görülebilen meatal stenoz ile üretral stenoz ve glans nekrozudur. Bu yan etkiler hastaların yaşam kalitesini ciddi şekilde etkilemektedir $(24,25)$.

\section{T2 ve Üstü Hasta Grubu Tedavi Yönetimi}

Korpus spongiozum ve korpus kavernozum tutulumları olan hastaların tedavi yönetimleri farklıdır. Eğer korpus spongiozum ve glansa sınırlı T2 hasta varsa tedavi seçenekleri glansektomi veya parsiyel penil amputasyondur. Lezyon $4 \mathrm{~cm}$ 'den küçükse RT denenebilir. Korpus kavernozum ve/veya üretra tutulumu varsa parsiyel amputasyon seçeneği standart tedavi seçeneğidir. RT yine bir seçenektir (26). T3 tümörler için standart tedavi yaklaşımı perineal üretrostomi ile beraber total penektomidir. T4 hastalık grubunda fikse LAP tedavisi için öncelikle neoadjuvant KT sonrasında cerrahi uygulanabilir (6).

Penis koruyucu cerrahi yapıldıktan sonra lokal rekürrens gelişmişse rekürrensin evresine göre hareket edilir. Eğer korpus kavernozum tutulumu yoksa tekrar penis koruyucu cerrahi uygulanabilir ancak daha ileri bir evre rekürrens varsa tedavi seçeneği parsiyel veya total ampütasyonla beraber fallik rekonstrüksiyonu gerektirir (27).

\section{Rejyonel Lenf Nodlarının Tedavi Yönetimi}

Penis kanserlerinde lenfatik metastazlar bazı anatomik kuralları takip ederler. Penis kanserlerinde inguinal LAP bilateral olabilir ancak bir tarafta inguinal LAP gelişmeden aynı tarafta pelvik LAP olduğu çalışmalarda gösterilememiştir. Yine paraaortik ve parakaval LAP gelişimi pelvik LAP gelişimi sonrası olmaktadır ve bölgesel sayılmadığı için bu bölgedeki LAP'lar uzak metastaz olarak kabul edilmektedir. Penis kanserlerinde bölgesel lenf nodlarının tanısı ve tedavi yönetimi hastanın uzun dönem sağ kalımını belirlediğinden çok önemlidir. Bölgesel lenf nodlarının tedavi yönetimi evreye bağımlı olarak yapılır (6).

\section{Klinik Olarak Normal İnguinal Lenf Nodu Olan Hastaların (cN0) Tedavi Yönetimi}

Erken radikal inguinal lenfadenektomi (RILA) cN0 hasta grubunda bile 5 yıllık sağ kalımı çok olumlu olarak etkilemektedir. Bu hasta grubunda erken RíLA ile hasta sağ kalım oranları \%90'lar civarındayken, takip sırasında bölgesel rekürrens saptanan hastalarda bu oran \%40'lara düşmektedir $(28,29)$. Özetlemek gerekirse sadece Tis, TaG1 ve T1G1 hasta grubunda, hastanın da riski kabul etmesiyle yakın takip önerilebilir. cNO hasta grubunda USG, BT ve/veya MRG mikrometastazları belirlemede güvenilir sonuçlar vermemektedir. Bu durumda tanı için geliştirilen nomogramlar da aynı şekilde yetersiz kalmaktadır. İnce iğne aspirasyon biopsi sonuçları da güvenli bir şekilde mikrometastatik 
hastalığı elimine edememektedir (6). Bu hasta grubunda 2 tane kanıtlanmış invazif tanısal metod bulunmaktadır: Modifiye inguinal lenfadenektomi (MILA) ve dinamik sentinel lenf nodu biopsisi (DSNB). Bu iki tanısal metoda dahi \%10-\%15 yanlış negatiflik oranı olabileceği bildirilmektedir $(29,30)$. Eğer bu tanısal metodlardan herhangi birinde lenf nodu metastazı tespit edilirse yapılacak işlem ipsilateral RILA'dır.

\section{Palpabl İnguinal Nodu Olan Hastaların (cN1/N2) Tedavi Yönetimi}

Penis kanserli hastalarda uni- veya bilateral LAP olan hastalarda metastatik lenf nodu tutulumu olma olasılığı çok yüksektir. O yüzden eskiden uygulanılan önce birkaç hafta 'antibiyotik tedavisi verelim eğer geçmezse invazif tanısal metodları uygulayalım' yaklaşımı bugün için artık kabul görmemektedir. İnguinal lenf nodu metastazı penis kanserli hastalarda sağ kalımı çok ciddi şekilde etkilediği için palpabl lenf nodu olan hastalarda tanısal amaçla en agresif yöntemlerle başlamak gerekmektedir. Bu hastalarda DSNB yaparak vakit kaybedilmesi önerilmemektedir. Bunun yerine RILA'ya hazırlanmak ve bu işlemi uygularken başlangıçta frozen göndermek ve de sonucuna göre de işlemi tamamlamak gerekmektedir. RiLA terapotik olarak çok büyük avantajlar sağlasa da ciddi morbiditeleri olan bir cerrahidir. Bu morbiditeleri azaltmak için preoperatif profilaktik antibiyotik kullanımı, intraoperatif lenf nodu eksizyonu sonrası elektrokoagülasyon kaçınılması ve postoperatif dönemde de bacakları basınçı bandajlarla sarmak önerilmektedir. Bu cerrahiyle ilgili yara yeri enfeksiyonları, cilt nekrozu, lenfödem ve lenfosel oluşumu gibi komplikasyonlar göreli olarak sık bildirilmektedir $(31,32)$.

Pelvik lenf nodu pozitifliği olan hastaların prognozu sadece inguinal lenf nodu tutulumu olanlara göre çok daha kötüdür. Bu ikisinin de karşılaştıııldığı bir çalışmada 5 yıllık kansersiz sağ kalım oranları sırasıyla \%33,2 ve \%71 olarak bulunmuştur. Aynı çalışmada pelvik lenf nodu tutulumu riskini arttıran 3 faktör belirlenmiştir: üç ve daha fazla inguinal pozitif nod olması, 30 $\mathrm{mm}$ ve daha büyük çapta pozitif inguinal nod olması ve inguinal ekstranodal tutulum olması. Eğer hastada bir tarafta inguinal bölgede 2 veya daha fazla pozitif lenf nodu varsa veya ekstranodal tutulum varsa bu durum ipsilateral pelvik lenfadenektomiyi gerektirir. Penis kanserlerinde geçerli olan anatomik kurallar gereği ingunal tutulum olmadan pelvik tutulum olmayacağı için inguinal tutulum olmayan hastalarda pelvik lenfadenektomi yapmanın hastaya bir katkısı olmayacaktır $(33,34)$.

Adjuvan KT pn2/pN3 hasta grubunda önerilmektedir. Adjuvan RT ile ilgili sınırı bilgi olduğu için önerilmemektedir (6).

Fikse İnguinal Nodu Olan Hastaların (cN3) Tedavi Yönetimi Bu grup hastada primer RILA küratif olamayacağı ve destrüktif olacağı için önerilmemektedir. Neoadjuvan KT sonrasında klinik olarak yanıt veren hastalarda RILA önerilir. Bu hasta grubunda prognoz çok kötüdür ancak neoadjuvan KT'ye yanıt veren hastalarda \%37 gibi yüksek bir uzun dönem sağ kalım oranları verilmiştir (35).

RILA sonrası lenf nodu rekürrensi olan hastalarla ilgili net bir bilgi olmamakla beraber neoadjuvan/adjuvan KT'yi içeren multimodal yaklaşım önerilmektedir. Lenf nodu pozitif hastaların tedavisinde hiçbir basamakta RT'nin onkolojik sonuçlara pozitif etkisi olduğuna dair yayın bulunmamaktadır ve bu yüzden de önerilmemektedir (36).

\section{Kemoterapi}

Penis SHK'larının KT tedavisi olarak, baş, boyun, vajina, vulva ve anüs SHK'ları ile histopatolojik benzerliklerinden dolayı bu tümörlere sahip hastalarda olumlu yanıt verdiği geniş hasta serileri ile kanıtlanmış olan sisplatin ve taksan içeren rejimler üzerinde durulmaktadır (6).

RILA sonrası nod pozitif hastalarda adjuvan KT olarak sisplatin, 5-FU ve paklitakselden (dozataksel) oluşan rejimin 3 veya 4 siklus halinde rutin uygulanımı önerilmektedir (37).

Fikse veya relaps etmiş inguinal lenf nodu olan hastalarda neoadjuvan KT olarak bleomisin, metotreksat ve sisplatinden oluşan rejimin olumlu etkisi olduğu kanıtlanmıştır. Bu tedaviden yanıt alan hasta grubuna cerrahi tedavi uygulanmaktadır. Ancak bu rejimle ilgili önemli bir dezavantaj yan etkilerinin fazla olması ve tolerabilitesinin düşük olmasıdır (38). O yüzden bu hasta grubunda irinotekan ve sisplatin kombinasyonlu ile paklitaksel, sisplatin ve ifosfamid kombinasyonlu iki ayrı KT rejimi de denenmiştir. Henüz istenilen sonuçlara ulaşılamamış olmasa da tam yanıt veren hastalar da görülmüştür $(39,40)$.

İlerlemiş ve relaps etmiş hastalarda palyatif KT seçeneği olarak belirlenmiş bir KT rejimi henüz bulunmamaktadır. Ancak sisplatin ve gemsitabin kombinasyonu üzerinde durulmaktadır (41).

Lenf nodu pozitif hastalarda radyokemoterapi şeklinde bir kombinasyon tedavisi ile ilgili yeterli bilgi ve çalışma bulunmamaktadır. Bu yüzden bu tedavi kombinasyonu çalışmalar harici önerilmemektedir (42).

Penis kanserlerinde hedeflenmiş akıllı tedaviler konusunda umut verici bazı çalışmalar olsa da daha ileri çalışmalara ihtiyaç vardır. Bu çalışmalarda dirençli hastalarda anti-EGFR monoklonal antikorlar olan 'Panitumumab' veya 'Cetuximab' tek ajan olarak kullanılmıştır. Ayrıca tirozin kinaz inhibitörlerinin etkinliği üzerinde de durulmaktadır $(43,44)$.

\section{Takip}

Penis kanserlerinde takip lokal rekürrens ve rejyonel nodal rekürrens saptandığında yapılacak tedavinin kür anlamına gelebileceği için çok önem taşır. Ancak rejyonel nodal rekürrensin prognozu çok daha kötüdür. Takip şeması olarak rekürrensler ilk 2 yıl çok daha sık görüldüğü için her 3 ayda bir yapılırken 2 yıldan sonra 3-5 yıllar arasında 6 ayda bire düşmektedir. Takibin ana kısmını fizik muayene oluşturur. Bunun yanında şüphelenilen hastalarda nodal rekürrensi saptamak için BT ve MRG uygulanılabilir (6).

\section{Sonuçlar}

Penis kanserlerinde erken tanı ve tedavi, organ koruyucu yaklaşım sergileyebilmek açısından çok önemlidir. Bu açıdan bu nadir görülen hastalık grubunu iyi bilmek ve belli bir yaşın üzerindeki erkek hastalar penis lezyonu ile polikliniğe başvurduklarında bu lezyonları önemsemek belki de hastanın hayatını kurtaracaktır. Bazı risk faktörleri üzerinde uzlaşıya varıldığı tespit edilmekle beraber daha bu konu üzerinde katedilecek uzun bir yol bulunmaktadır. Özellikle henüz keşfedilmemiş cinsel yolla bulaşan viral ve bakteriyel latent enfeksiyonlarının bu hastalığın etiyolojisinde rolü olabileceği düşünülmektedir. Cinsel ilişki sıklığının ve partner sayısının arttığı ve ilk ilişki yaşının düşmeye başladığı günümüzde penis kanseri olgularının artacağını öngörmek yanlış olmaz. Ayrıca tanısında ve prognozu öngörmede de yetersiz kalan nomogramlar ve moleküler belirteçlerin ileride etkinliklerinin artacağı aşikardır.

Çıkar çatışması: Yazarlar bu makale ile ilgili olarak herhangi bir çıkar çatışması bildirmemişlerdir. 


\section{Kaynaklar}

1. Pettaway CA, Lance RS, Davis JW. Tumors of the penis. CampbellWalsh Urology, 10th edition. Editör: Alan J Wein. Saunders Elsevier, Philadelphia, 2012:901-933.

2. Özer MG. Penis tümörleri. Üroonkoloji kitabı. Editörler: Özen $H_{\text {, }}$ Türkeri L.1.Basım,Ertem Basım yayın, Ankara 2007:1315-1332.

3. Buechner SA. Common skin disorders of the penis. BJU Int 2002;90:498-506.

4. Bleeker MC, Heideman DA, Snijders PJ et al. Penile cancer: epidemiology, pathogenesis and prevention. World J Urol 2009;27:141-50.

5. Frimberger $D$, Hungerhuber $E$, Zaak $D$, et al. Penile carcinoma. Is Nd:YAG laser therapy radical enough? J Urol 2002;168:2418-2421.

6. Hakenberg OW, Comperat E, Minhas S. Penile cancer. EAU Guidelines. Edition presented at the EAU Annual Congress Stockholm 2014. ISBN:978-90-79754-65-6.

7. Misra S, Chaturvedi A, Misra NC. Penile carcinoma: a challenge for the developing world. Lancet Oncol 2004;5:240-247.

8. Wiener JS, Walther PJ. The association of oncogenic human papillomaviruses with urologic malignancy. The controversies and clinical implications. Surg Oncol Clin N Am 1995;4:257-276.

9. Ornellas AA, Seixas AL, Marota A, et al. Surgical treatment of invasive squamous cell carcinoma of the penis: retrospective analysis of 350 cases. J Urol 1994;151:1244-1249.

10. Malakoff AF, Schmidt JD. Metastatic carcinoma of penis complicated by hypercalcemia. Urology 1975;5:510-513.

11. Scardino E, Villa G, Bonomo G, et al. Magnetic resonance imaging combined with artificial erection for local staging of penile cancer. Urology 2004;63:1158-1162.

12. Vapnek JM, Hricak H, Carroll PR. Recent advances in imaging studies for staging of penile and urethral carcinoma. Urol Clin North Am 1992; 19:257-266.

13. Lont AP, Besnard AP, Gallee MP, et al. A comparison of physical examination and imaging in determining the extent of primary penile carcinoma. BJU Int 2003;91:493-495.

14. Horenblas S, Van Tinteren H, Delemarre JF, et al. Squamous cell carcinoma of the penis: accuracy of tumor, nodes and metastasis classification system, and role of lymphangiography, computerized tomography scan and fine needle aspiration cytology. J Urol 1991; 146:1279-1283.

15. Tabatabaei S, Harisinghani M, McDougal WS. Regional lymph node staging using lymphotropic nanoparticle enhanced magnetic resonance imaging with ferumoxtran-10 in patients with penile cancer. J Urol 2005; 174:923-927.

16. Scher B, Seitz $M$, Reiser $M$, et al. 18F-FDG PET/CT for staging of penile cancer. I Nucl Med 2005;46:1460-1465.

17. Horenblas $S$, van Tinteren $H$. Squamous cell carcinoma of the penis. IV. Prognostic factors of survival: analysis of tumor, nodes and metastasis classification system. J Urol 1994;151:1239-1243.

18. Alnajjar HM, Lam W, Bolgeri $M$, et al. Treatment of carcinoma in situ of the glans penis with topical chemotherapy agents. Eur Urol 2012;62:923-928.

19. Philippou $P$, Shabbir $M$, Malone $P$, et al. Conservative surgery for squamous cell carcinoma of the penis: resection margins and longterm oncological control. J Urol $2012 ; 188: 803-808$.

20. Ornellas AA, Kinchin EW, Nóbrega BL, et al. Surgical treatment of invasive squamous cell carcinoma of the penis: Brazilian National Cancer Institute long-term experience. J Surg Oncol 2008;97:487-495.

21. Bandieramonte G, Colecchia M, Mariani L, et al. Peniscopically controlled $\mathrm{CO} 2$ laser excision for conservative treatment of in situ and T1 penile carcinoma: report on 224 patients. Eur Urol 2008;54:875-882.

22. Meijer RP, Boon TA, van Venrooij GE, et al. Long-term follow-up after laser therapy for penile carcinoma. Urology 2007;69:759-762.

23. Rothenberger $\mathrm{KH}$, Hofstetter A. Laser therapy of penile carcinoma. Urologe 1994;33:291-294.
24. Crook J, Jezioranski J, Cygler JE. Penile brachytherapy: technical aspects and postimplant issues. Brachytherapy 2010;9:151-158.

25. Crook J, Ma C, Grimard L. Radiation therapy in the management of the primary penile tumor: an update. World J Urol 2009;27:189-196.

26. Azrif M, Logue JP, Swindell R, et al. External-beam radiotherapy in T1-2 N0 penile carcinoma. Clin Oncol (R Coll Radiol) 2006;18:320-325.

27. Smith $Y$, Hadway $P$, Biedrzycki $O$, et al. Reconstructive surgery for invasive squamous carcinoma of the glans penis. Eur Urol 2007; 52:1179-1185.

28. Zhu Y, Zhang HL, Yao XD, et al. Development and evaluation of a nomogram to predict inguinal lymph node metastasis in patients with penile cancer and clinically negative lymph nodes. J Urol 2010;184:539-545.

29. Kirrander P, Andrén O, Windahl T. Dynamic sentinel node biopsy in penile cancer: initial experiences at a Swedish referral centre. BJU Int 2013;111:48-53.

30. Djajadiningrat RS, Teertstra HJ, Van Rhijn BW, et al. Value of dynamic sentinel node biopsy, ultrasound and fine needle aspiration in the detection of metastatic lymph nodes in penile cancer. Eur Urol Suppl 2013;12;394.

31. La-Touche S, Ayres B, Lam W, et al. Trial of ligation versus coagulation of lymphatics in dynamic inguinal sentinel lymph node biopsy for staging of squamous cell carcinoma of the penis. Ann R Coll Surg Engl 2012;94:344-346.

32. Yao $\mathrm{K}, \mathrm{Tu} \mathrm{H}$, $\mathrm{Li} \mathrm{YH}$, et al. Modified technique of radical inguinal lymphadenectomy for penile carcinoma: morbidity and outcome. I Urol 2010;184:546-552.

33. Tobias-Machado M, Tavares A, Ornellas AA, et al. Video endoscopic inguinal lymphadenectomy: a new minimally invasive procedure for radical management of inguinal nodes in patients with penile squamous cell carcinoma. J Urol 2007;177:953-957.

34. Lughezzani $G$, Catanzaro $M$, Torelli $T$, et al. The relationship between characteristics of inguinal lymph-nodes and pelvic lymph-node involvement in penile squamous cell carcinoma: a single-institutional experience. J Urol 2014;191:977-982.

35. Pizzocaro G, Piva L. Adjuvant and neoadjuvant vincristine, bleomycin, and methotrexate for inguinal metastases from squamous cell carcinoma of the penis. Acta Oncol 988;27:823-824.

36. Graafland NM, Moonen LM, van Boven $\mathrm{HH}$, et al. Inguinal recurrence following therapeutic lymphadenectomy for node positive penile carcinoma: outcome and implications for management. J Urol 2011;185:888-893.

37. Noronha V, Patil V, Ostwal V, et al. Role of paclitaxel and platinumbased adjuvant chemotherapy in high-risk penile cancer. Urol Ann 2012;4:150-153.

38. Haas GP, Blumenstein BA, Gagliano RG, et al. Cisplatin, methotrexate and bleomycin for the treatment of carcinoma of the penis: a Southwest Oncology Group study. J Urol 1999 ;161:1823-1825.

39. Theodore C, Skoneczna I, Bodrogi I, et al. A phase II multicentre study of irinotecan (CPT 11) in combination with cisplatin (CDDP) in metastatic or locally advanced penile carcinoma (EORTC PROTOCOL 30992). Ann Oncol 2008;19:1304-1307.

40. Pagliaro LC, Williams DL, Daliani D, et al. Neoadjuvant paclitaxel, ifosfamide, and cisplatin chemotherapy for metastatic penile cancer: a phase II study. J Clin Oncol 2010;28:3851-3857.

41. Power DG, Galvin DJ, Cuffe $S$, et al. Cisplatin and gemcitabine in the management of metastatic penile cancer. Urol Oncol 2009;27:187-190.

42. Eliason M, Bowen A, Hazard L, et al. Primary treatment of verrucous carcinoma of the penis with fluorouracil, cis-diamino-dichloroplatinum, and radiation therapy. Arch Dermatol 2009;145:950-952.

43. Gou HF, Li X, Qiu M, et al. Epidermal growth factor receptor (EGFR)RAS signaling pathway in penile squamous cell carcinoma PLoS One 2013;8:62175.

44. Zhu Y, Li H, Yao XD, et al. Feasibility and activity of sorafenib and sunitinib in advanced penile cancer: a preliminary report. Urol Int 2010;85:334-340. 